\title{
PENGARUH INTEREST RATE, INVESTOR SENTIMENT, FINANCIAL DISTRESS TERHADAP STOCK RETURN
}

\author{
Nurainun Bangun \\ Feren \\ Linda Santioso \\ Henryanto Wijaya
}

Universitas Tarumanagara, Jakarta

Email: henryanto.wijaya@gmail.com

\begin{abstract}
:
The purpose of this research is to know the effect of interest rate, investor sentiment, and financial distress of stock return on manufacturing company listed on the Indonesia Stock Exchange from 2014-2017. The sampling method used in this research used 49 manufacturing company that were selected using purposive sampling method. Data used for this study is obtained from financial statement for the year ended December $31^{\text {st }}$ during 2014-2017. Analysis tool that will be used to analyze the hypothesis with multiple linier regression model is software IBM SPSS (Statistical Product and Service Solutions) version 23.0 for Windows. The result for this research showed that interest rate and investor sentiment have positive and significant effect on stock return, while financial distress has negative and significant effect on stock return.
\end{abstract}

Keywords: Stock Return, Interest Rate, Investor Sentiment, Financial Distress

\section{PENDAHULUAN}

Di era globalisasi ini, banyak ditemukan perusahaan manufaktur yang berkembang pesat di Indonesia. Mereka berusaha untuk memproduksi barang yang memiliki kualitas tinggi dengan biaya yang rendah untuk meningkatkan daya saing di pasar domestik maupun pasar global. Jika usaha yang dijalankan suatu perusahaan bertambah besar, dana yang diperlukan pun semakin besar. Ada beberapa cara bagi perusahaan dalam memperoleh dana untuk membiayai usaha produksinya seperti menggunakan laba yang telah diperoleh atas penjualan periode sebelumnya, namun perusahaan tidak bisa hanya bergantung pada dana tersebut saja, tetapi membutuhkan dana dari sumber lain yang berasal dari luar perusahaan. Salah satunya melalui pasar modal (Yaradeta, 2014:1). Apabila sebuah perusahaan tidak mempunyai modal atau kekurangan modal, maka pasar modal menyediakan dana untuk operasi perusahaan baik untuk public sector 
maupun private sector (Al Oshaibat, 2016: 15). Pasar modal juga sebagai sarana bagi para investor untuk berinvestasi dengan harapan mendapatkan return yang sesuai, serta biaya likuidasi yang rendah. Return saham didefinisikan sebagai hasil keuntungan atau kerugian yang diperoleh dari sebuah investasi saham. Perbedaan antara harga investasi saat ini yang lebih tinggi dari periode sebelumnya maka akan memberikan capital gain, bila sebaliknnya maka akan terjadi capital loss (Michael, 2014:45). Sekarang ini banyak investor baik dalam negeri atau luar negeri melakukan investasi dalam bentuk saham, dikarenakan keuntungannya lebih besar. Keuntungan bagi para investor ini disebut return (pengembalian). Secara umum, return diartikan sebagai level keuntungan dari sebuah investasi (Smart, Gitman, \& Joehnk, 2014:150). Pengukuran return saham sangat penting bagi investor. Tetapi dalam melakukan investasi tentu ada risiko yang dihadapi. Untuk meminimalisir risiko terhadap pengembalian saham, maka investor dapat melakukan analisis terlebih dahulu atas faktor yang mempengaruhi pengembalian saham sebelum melakukan investasi pada suatu perusahaan. Pengukuran pengembalian saham ini penting bagi investor untuk menilai seberapi baik saham yang diinvestasikan dan juga menilai kinerja perusahaan. Investasi saham yang baik adalah saham yang bisa menyediakan return yang hampir sesuai dengan expected return. Pengembalian saham bisa berasal dari banyak faktor, seperti bagaimana cara mempertahankan keuntungan yang sudah dicapai oleh perusahaan. Interest rate memiliki dampak langsung terhadap kondisi perekonomian. Berbagai keputusan yang berhubungan dengan konsumsi, investasi dan tabungan terkait erat dengan kondisi interest rate. Faktor interest rate ini penting untuk diperhitungkan karena investor dapat mengharapkan hasil investasi yang lebih besar. Kenaikan interest rate akan meningkatkan beban bunga emiten, sehingga perolehan laba menurun. Selain itu, pada saat interest rate tinggi, biaya produksi meningkat, sehingga harga produk menjadi lebih mahal, dan konsumen akan menunda pembelian, sehingga penjualan perusahaan menurun. Bachtriyoh menyatakan bahwa tingkat suku bunga menunjukkan kinerja perusahaan dalam 
menghasilkan harga saham dan juga laba. Tandelilin (dalam Akbar Fauriko, 2013:25) mengatakan bahwa variabel ekonomi makro yang perlu diperhatikan investor antara lain adalah tingkat suku bunga, tingkat inflasi, kurs rupiah, produk domestik bruto (PDB), dan anggaran defisit. Kegiatan - kegiatan yang memperkuat perekonomian merupakan dorongan pertumbuhan laba dan pendapatan perusahaan sehingga mendorong peningkatan harga saham. Terdapat penelitian tentang tingkat suku bunga terhadap return saham oleh Ouma dan Muriu (2014:109), yang menunjukkan hasil bahwa tingkat suku bunga tidak berpengaruh terhadap return saham. Hasil penelitian tersebut berbeda dengan penelitian yang dilakukan oleh Hayat dan Nisar Ahmed (2014:87) yang menunjukkan hasil tingkat suku bunga berpengaruh negatif terhadap return saham. Tingkat suku bunga memiliki dampak negative terhadap harga saham dan return saham. Pada tingkat bunga pinjaman yang tinggi, beban bunga kredit meningkat dan dapat menyebabkan penurunan laba bersih. Di sisi lain, kenaikan suku bunga deposito dapat menyebabkan investor menjual sahamnya untuk berinvestasi ke deposito. Hal tersebut menyebabkan jatuhnya harga saham akibat penjualan saham secara besarbesaran (Samsul (2006), dalam Amin Sobri, (2018:14) Berdasarkan pada penelitian di atas, maka peneliti menentukan interest rate sebagai salah satu variabel independen. Setiap investor itu berbeda antara yang satu dengan yang lainnya, begitu juga dengan sentimen mereka. Kenneth L. Fricher (2003:115) menyatakan bahwa sentimen dari strategi Wall Street tidak berhubungan antara sentimen satu investor dengan sentimen investor lainnya. Sentimen investor tidak dapat dihitung, tetapi menggunakan indikator yang mendukung sentimen tersebut. Indikator yang mendukung tersebut adalah trading volume, consumer confidence index, dan market turnover. Beberapa tahun terakhir ini, ada pembelajaran mengenai sentimen. Namun hal tersebut belum sempurna diteliti. Oleh karena itu perlu penelitian lebih lanjut mengenai sentimen dan hubungannya dengan pengembalian saham. Dalam penelitian terbaru yang dilakukan oleh Aissia (2016), menguji efek dari sentimen investor lokal dengan sentimen investor luar pada pasar modal Perancis dan hasilnya kedua sentimen mempengaruhi 
pengembalian saham. Sentimen dapat mempengaruhi pendapat investor karena kesalahan harga terjadi di pasar modal. Investor bisa saja optimis atau pesimis. Investor yang optimis dalam melakukan investasi akan mendorong harga saham tersebut naik begitu juga sebaliknya. Menurut Brown dan Cliff (dalam Anusakumar, Ali, dan Choo Wei, 2017:161) bahwa sentimen mempengaruhi pengembalian saham pada pasar modal di Amerika Serikat. Sedangkan Chen (dalam Anusakumar, Ali, dan Choo Wei, 2017:162) berpendapat bahwa sentimen berpengaruh negatif terhadap pengembalian saham di pasar modal Amerika Serikat. Secara keseluruhan, karakteristik dari sebuah perusahaan disarankan menjadi faktor penentu apakah sentimen mempengaruhi pengembalian saham. Lee, Shleifer dan Thaler (dalam Anusakumar, Ali, dan Choo Wei, 2017:162), menyimpulkan perusahaan yang kecil paling terpengaruh dengan sentimen disbanding perusahaan besar. Berdasarkan pada penelitian di atas, maka peneliti menentukan investor sentiment sebagai salah satu variabel independen. Sebuah perusahaan bisa dikatakan mengalamai kegagalan keuangan jika perusahaan tersebut tidak dapat membayar utangnya pada saat jatuh tempo, walaupun mempunyai aset yang lebih banyak dibandingkan dengan kewajiban. Kondisi yang membuat investor dan kreditur khawatir adalah ketika perusahaan menghadapi financial distress yang mengarah ke arah kebangkrutan. Jika perusahaan memberikan tanda kegagalan finansial, maka perusahaan tersebut tidak dapat memberikan keuntungan kepada pemegang sahamya dan harga saham perusahaan tersebut akan turun dan ditolak. Apabila biaya produksi semakin meningkat sedangkan harga penjualan semakin menurun, hal itu dapat menyebabkan kerugian perusahaan. Jika terjadi terus-menerus dapat mengakibatkan financial distress bahkan mengalami kebangkrutan perusahaan (Yunanto, 2017:453). Financial distress yang tinggi menggambarkan kondisi perusahaan yang buruk. Financial distress akan naik ketika perusahaan mengalami kerugian. Kondisi perusahaan yang buruk biasanya direspon kurang baik dengan turunnya harga saham sehingga ikut mempengaruhi return saham bagi investor. Berdasarkan pada penelitian di atas, maka peneliti menentukan 
financial distress sebagai salah satu variabel independen. Pengukuran return saham sangat penting bagi investor. Tetapi dalam melakukan investasi tentu ada risiko yang dihadapi. Untuk meminimalkan risiko terhadap pengembalian saham, maka investor dapat melakukan analisis terlebih dahulu atas faktor yang mempengaruhi pengembalian saham sebelum

\section{TELAAH LITERATUR}

Teori sinyal (Signaling Theory) adalah perilaku manajemen perusahaan dalam memberikan petunjuk kepada investor tentang bagaimana pandangan manajemen dalam prospek perusahaan di masa yang akan datang (Brigham \& Hosuton, 2014:184). Teori sinyal menjelaskan bagaimana sebuah perusahaan memberikan sinyal kepada pengguna laporan keuangan. Sinyal ini berupa informasi mengenai apa yang sudah dilakukan oleh manajemen untuk merealisasikan keinginan pemilik. Sinyal dapat berupa promosi atau informasi lain yang menyatakan bahwa perusahaan tersebut lebih baik daripada perusahaan lain. Manajer memberikan informasi melalui laporan keuangan bahwa mereka menerapkan kebijakan melakukan investasi pada suatu perusahaan. Pengukuran pengembalian saham ini penting bagi investor untuk menilai seberapa baik saham yang diinvestasikan dan juga menilai kinerja perusahaan. Beberapa faktor yang dapat mempengaruhi pengembalian saham yaitu interest rate, investor sentiment, dan financial distress.

akuntansi konservatisme yang menghasilkan laba yang lebih berkualitas, karena prinsip ini mencegah perusahaan melakukan tindakan membesar-besarkan laba dan membantu pengguna laporan keuangan dengan menyajikan laba dan aktiva yang tidak overstate. Laporan keuangan merupakan sarana mengkomunikasikan informasi keuangan utama kepada pihak-pihak di dalam maupun di luar perusahaan. Laporan keuangan dapat menunjukkan informasi kinerja perusahaan pada periode tertentu, sehingga pengambilan keputusan investasi menjadi tepat (Iskandarsyah dkk., 2014). Sinyal ini berupa informasi mengenai apa yang sudah dilakukan manajemen untuk merealisasikan keinginan pemilik (Syamsull, 2006 dalam Mirantiani, 
2016). Teori sinyal ini menekankan pada pentingnya informasi yang dikeluarkan oleh perusahaan terhadap keputusan investasi kepada pihak lain jangan sampai terjadi ketidakseimbangan informasi. Adanya ketidakseimbangan penguasaan informasi akan memicu munculnya kondisi yang disebut sebagai asimetri informasi. Teori sinyal menjelaskan bahwa pemberian sinyal dilakukan oleh manajer untuk mengurangi asimetri informasi. Informasi laba dan pengumuman dividen dapat memberikan sinyal atau informasi kepada investor mengenai prospek perusahaan di masa yang akan datang (Mirantiani, 2016). Jika prospek perusahaan di masa yang akan datang baik maka pendapatan dan aliran kas diharapkan meningkat sehingga perusahaan dapat meningkatkan pembayaran dividennya. Perusahaan akan membagikan dividennya apabila suatu perusahaan tersebut memperoleh keuntungan yang besar, hal ini akan memberikan sinyal yang positif bagi para investor karena semakin besar keuntungan yang didapat perusahaan maka jumlah kas yang dimiliki perusahaan akan ikut meningkat dan perusahaan tersebut dapat membagikan dividen dalam jumlah yang besar kepada para investor (Rosnah, 2007 dalam Mirantiani, 2016). Teori keagenan adalah hubungan antara principal dan agent. Principal adalah sebutan bagi investor, sedangkan agent adalah sebutan bagi manajemen. Jensen dan Meckling (1976) memberikan pengertian teori agen yaitu "Agency Theory primarily deals with the principal-agent relationship (also referred to as the agency relationship) existing in the separation of ownership and management, or in the separation of risk bearing, decision making and management functions." Teori keagenan memiliki asumsi bahwa setiap individu seakan-akan termotivasi oleh kepentingan dirinya sendiri sehingga menimbulkan konflik kepentingan antara principal dan agent. Hubungan ini tidak selalu harmonis, teori keagenan berkaitan dengan konflik agency, atau konflik kepentingan antara agen dan pelaku. Konflik terjadi karena adanya sikap opportunistic. Sikap opportunistic adalah sikap manajemen untuk memaksimalkan kesejahteraannya sendiri, dimana sikap tersebut bertolakbelakang dengan kepentingan dan harapan dari principal, yang dapat dilakukan dengan sengaja oleh 
manajemen. Beberapa contoh sikap opportunistic yaitu :

1. Membuat laporan piutang tak tertagih (bad debt) yang lebih besar.

2. Membuat laporan penjualan mengalami peningkatan yang kecil.

3. Membuat laporan kepada pihak principal bahwa dibutuhkan dana tambahan untuk operasional

4. Melakukan income smoothing, yaitu membuat laporan laba yang tidak sesuai dengan kenyataan.

Dalam teori keagenan, manajer sebagai agent adalah pihak yang memiliki informasi lengkap dalam perusahaan. Tetapi kadang ada informasi perusahaan yang tidak dinyatakan oleh manajer kepada investor. Oleh karena itu dibutuhkan pengawasan dan pengendalian untuk memastikan bahwa apa yang dilakukan manajer sesuai dengan ketentuan yang berlaku dalam perusahaan. Pengawasan dan pengendalian yang dilakukan membutuhkan biaya yang disebut agency cost. Agency cost adalah biaya kegiatan pengawasan dan pengendalian terhadap perilaku manajer agar tidak menyimpang dan sesuai dengan harapan pemegang saham. Teori sinyal (Signaling Theory) adalah tingkah laku manajemen perusahaan dalam memberikan petunjuk kepada investor tentang bagaimana pandangan manajemen dalam prospek perusahaan di masa yang akan datang (Brigham \& Hosuton, 2014). Teori sinyal menjelaskan cara perusahaan dalam menyampaikan sinyal kepada pengguna laporan keuangannya. Sinyal tersebut berupa informasi mengenai hal-hal yang dilakukan manajemen dalam merealisasikan keinginan pemilik. Hubungan teori sinyal antara investor sentiment dengan stock return adalah teori sinyal ini menekankan pada pentingnya informasi yang dikeluarkan oleh perusahaan terhadap keputusan investasi kepada pihak lain (investor) agar jangan sampai terjadi ketidakseimbangan informasi. Agency Theory. Teori keagenan adalah hubungan antara principal dan agent. Principal adalah sebutan bagi investor, sedangkan agent adalah sebutan bagi manajemen. Teori keagenan diasumsikan bahwa setiap individu seakan-akan termotivasi dari dirinya sendiri sehingga timbul konflik antara 
principal dan agent. Hubungan principal dan agent tidak selalu harmonis, oleh karena itu timbul yang namanya konflik agency, atau konflik kepentingan antara agen dan pelaku. Konflik terjadi karena adanya sikap opportunistic. Sikap opportunistic adalah sikap manajemen untuk memaksimalkan kesejahteraannya sendiri, dimana sikap tersebut bertolakbelakang dengan kepentingan dan harapan dari principal. Dalam teori keagenan, manajer sebagai agent adalah pihak yang memiliki informasi lengkap dalam perusahaan. Tetapi kadang ada informasi perusahaan yang tidak dinyatakan oleh manajer kepada investor. Hubungan teori keagenan antara investor sentiment dengan stock return adalah terjadi konflik maka akan menimbulkan sentimen yang tidak baik dari investor sehingga mempengaruhi stock return. Kemudian hubungan teori keagenan antara financial distress dengan stock return adalah sikap opportunistic yang dapat mempengaruhi informasi laporan keuangan yang diterima oleh investor. Return adalah tingkat keuntungan yang diperoleh investor atas investasi yang dilakukannya pada suatu perusahaan (Hadi, 2013:194). Pengertian return adalah keuntungan yang didapatkan oleh suatu perusahaan, individu dan institusi atas investasi yang dilakukannya. Tujuan seseorang melakukan investasi adalah untuk mendapatkan pengembalian (return) atas dana yang telah diinvestasikan pada sebuah perusahaan. Menurut Jogiyanto (2014:.235) return saham dapat dibagi menjadi dua jenis, yaitu :

1. Return Realisasian (Realized Return) adalah return yang sudah terjadi yang dihitung dengan menggunakan data historis. Return realisasian digunakan sebagai data analisis investasi, serta digunakan sebagai data analisis portofolio.

2. Return Ekspektasian (Expected Return) adalah return yang diharapkan oleh investor di masa yang akan datang. Return ekspektasian digunakan sebagai input dari analisis portofolio.

Dari pengertian return saham yang disebutkan di atas, maka dapat ditarik kesimpulan bahwa return saham adalah tingkat pengembalian atau keuntungan yang diperoleh para investor atas investasi yang telah dilakukan. Interest rate (suku bunga) adalah nilai, tingkat, 
harga atau keuntungan yang diberikan kepada investor dari penggunaan dana investasi atas dasar perhitungan nilai ekonomis dalam periode waktu tertentu. Tingkat suku bunga bank digunakan untuk mengontrol perekonomian suatu negara. Kenaikan suku bunga yang tidak wajar menyulitkan dunia usaha untuk membayar beban bunga dan kewajiban, karena suku bunga yang tinggi akan menambah beban bagi perusahaan sehingga secara langsung akan mengurangi profit perusahaan. Menurut Boediono (2014:76), interest rate adalah harga dari penggunaan dana investasi. Tingkat suku bunga merupakan salah satu indikator dalam menentukan apakah seseorang akan melakukan investasi atau menabung. Pengertian interest rate menurut Sunariyah (2013:80) adalah harga dari pinjaman. Suku bunga dianggap sebagai persentase uang pokok per unit waktu. Bunga merupakan ukuran harga atas sumber daya yang digunakan oleh debitur yang dibayarkan kepada kreditur. Suku bunga dapat dibedakan menjadi dua, yaitu suku bunga nominal dan suku bunga riil. Suku bunga nominal adalah rate yang diamati dalam pasar. Suku bunga riil adalah konsep yang menghitung tingkat bunga yang sesungguhnya, suku bunga riil dihitung dengan cara suku bunga nominal dikurangi dengan laju inflasi yang diharapkan. Investor sentiment adalah kecenderungan para investor berspekulasi. Investor Sentiment merupakan bagian dari ekspresi perilaku keuangan. Stefan dan Laura (2014:27) mengatakan sentimen adalah sebuah penilaian yang sangat menentukan dalam investasi saham di bursa dan menjadi penentu pergerakan harga saham. Baker dan Wugler (dalam Fadhillah \& Faisal, 2017:247) mengatakan investor sentiment merupakan perilaku investor yang cenderung berspekulasi dengan pengaruh psikologi seseorang. Maka pada kondisi tertentu investor tidak rasional dalam menilai risiko dan return. Investor sentiment merupakan keyakinan investor terhadap arus kas perusahaan di masa depan yang tidak didukung oleh informasi fundamental. Perusahaan dalam menjalankan usahanya tidak mampu memenuhi permintaan pasar (konsumen) dan tidak mampu bersaing dengan perusahaan lainnya, cepat atau lambat akan mengalami kebangkrutan. Terjadinya kesulitan keuangan dalam suatu perusahaan mencerminkan 
ketidakmampuan perusahaan untuk bertahan dan survive dari segala permasalahan yang dihadapi perusahaan dalam dunia bisnis. Vinh (2015:56) menyebutkan bahwa kesulitan keuangan atau financial distress merupakan sebuah kondisi permasalahan perekonomian yang dialami oleh perusahaan sebagai bentuk dari kemunduran kinerja sebelum perusahaan mengalami kebangkrutan. Financial distress adalah kondisi dimana keuangan perusahaan sedang dalam keadaan tidak sehat atau krisis. Kondisi ini diawali dengan kesulitan likuiditas dimana perusahaan kesulitan untuk memenuhi kewajibannya kepada kreditur (Zahara, 2013:26). Drescher
(2014:25) mengatakan bahwa financial distress merupakan tahap akhir dari krisis likuiditas yang memiliki potensi mengalami kebangkrutan. Perusahaan sedang mengalami kesulitan dalam memenuhi kewajibannya yang sudah jatuh tempo. Menurut Gamayumi (dalam Ellen dan Juniarti, 2013) ada beberapa klasifikasi mengenai financial distress, yaitu : Economic Failure, Business Failure, Technical Insolvency, Insolvency in Bankruptcy Sense, Legal Bankruptcy. Kerangka pemikiran yang digambarkan dalam penelitian ini adalah sebagai berikut :

\section{Gambar 1 Kerangka Pemikiran}

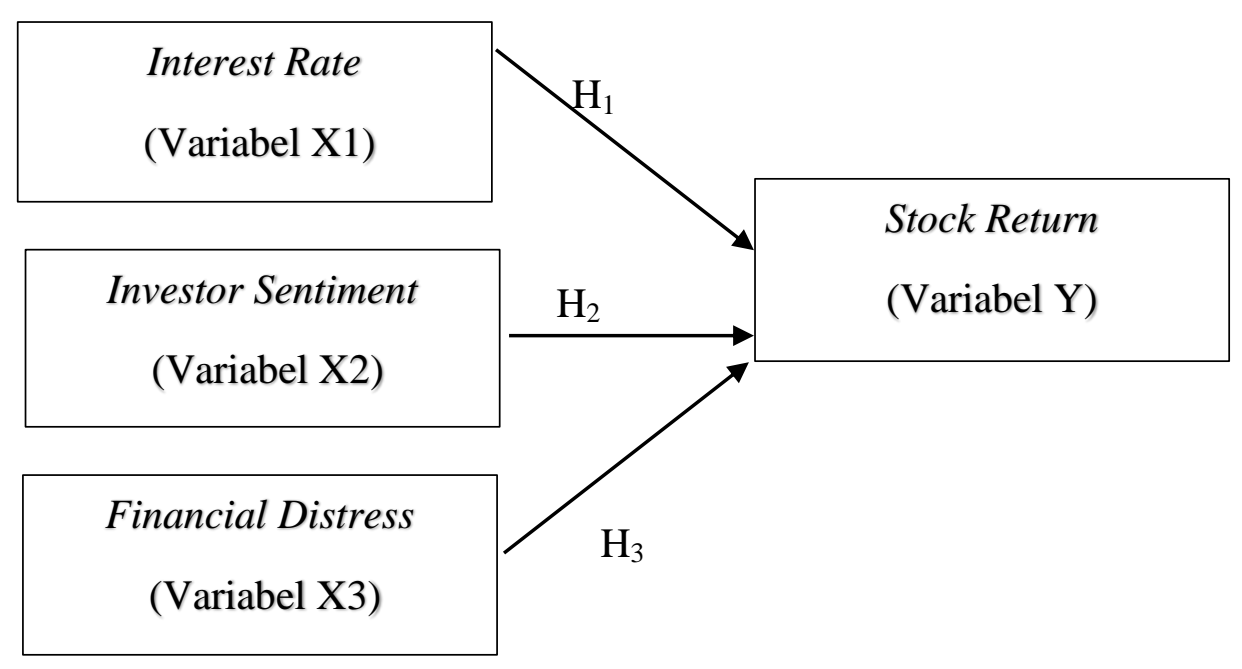


Berdasarkan kerangka pemikiran diatas, dibuat hipotesis dalam penelitian ini yaitu :

1. $\mathrm{H}_{1}$ : Terdapat pengaruh signifikan dan positif antara interest rate terhadap stock return

\section{METODOLOGI PENELITIAN}

Penelitian

dilakukan

untuk

menunjukkan

kebenaran

dan

pemecahan masalah atas apa yang diteliti. Untuk melakukan penelitian digunakan suatu metode yang tepat dan relevan. Menurut Sugiyono (2014, h.2) metode penelitian adalah cara ilmiah untuk mendapatkan data dengan tujuan dan kegunaan tertentu. Pendekatan penelitian yang digunakan penulis dalam penelitian ini adalah pendekatan kuantitatif. Metode yang digunakan pada penelitian ini adalah metode penelitian kuantitatif atau data sekunder (secondary data analysis). Menurut Sugiyono (2014:31) yang dimaksud metode kuantitatif adalah metode penelitian yang berlandaskan pada filsafat positivisme, digunakan untuk meneliti pada populasi atau sampel tertentu, teknik pengambilan sempel pada umumnya dilakukan secara random, pengumpulan data
2. $\mathrm{H}_{2}$ : Terdapat pengaruh signifikan positif antara investor sentiment terhadap stock return

3. $\mathrm{H}_{3}$ : Terdapat pengaruh signifikan dan negatif antara financial distress terhadap stock return

menggunakan instrumen penelitian, analisis data bersifat kuantitatif dengan tujuan untuk menguji hipotesis yang telah ditetapkan. Berdasarkan pemahaman di atas, metode penelitian kuantitatif atau secondary data analysis merupakan sejumlah data yang dikumpulkan karena adanya tujuan yang berisikan sumber bisnis suatu perusahaan. Data sekunder yang digunakan pada penelitian ini didapatkan dari perdagangan bursa saham dan internet. Yang menjadi subjek penelitian adalah perusahaan perusahaan manufaktur yang terdaftar di Bursa Efek Iindonesia pada tahun 20142017. Sedangkan yang menjadi objek penelitian adalah stock return (variabel $\mathrm{Y}$ ), interest rate (variabel $\mathrm{X}_{1}$ ), investor sentiment (variabel $\mathrm{X}_{2}$ ), dan financial distress (variabel $\mathrm{X}_{3}$ ). Pemilihan sampel dalam penelitian ini menggunakan metode purposive sampling yaitu teknik judgemental (penilaian), dimana unsur 
populasi ditentukan berdasarkan tujuan penelitian. Teknik ini dapat digunakan jika karakteristik dan objek penelitian telah diketahui. Kriteria sampel dalam penelitian ini adalah a) Perusahaan manufaktur yang terdaftar pada Bursa Efek Indonesia (BEI) pada tahun 2014 2017. b) Perusahaan yang mengalami IPO, delisting, dan relisting pada tahun 2014-2017. c) Data dan informasi yang lengkap untuk mendukung variabel financial distress yang digunakan untuk menganalisis nilai perusahaan pada tahun 2014 - 2017. d)Laporan keuangan yang berakhir pada tanggal 31 Desember dan diterbitkan secara berturut-turut tahun 2014 - 2017. e) Perusahaan yang menyajikan laporan keuangan menggunakan mata uang rupiah (IDR). Untuk menghitung return total digunakan rumus :

$$
\mathrm{r}: \frac{P t-P t 1}{P t 1}
$$

Keterangan :

$\mathrm{r}$ : Return saham

Pt : Harga saham penutupan pada hari ke $t$

$\mathrm{Pt}_{1}$ : Harga saham pentupan pada hari ke $\mathrm{t}-1$ ( hari sebelumnya)

Interest rate (suku bunga $\mathrm{BI}$ ) adalah kebijakan yang mengatur suku bunga atau kebijakan moneter yang ditetapkan oleh Bank Indonesia. Dalam penelitian ini tingkat suku bunga yang digunakan sebagai variabel adalah tingkat suku bunga BI. Satuan yang digunakan adalah satuan persen dan data yang diambil adalah tingkat Suku Bunga BI per tahun 2014 - 2017. Rasio yang digunakan oleh peneliti untuk mengukur indeks investor sentiment yaitu dengan menggunakan proksi trading volume (Faisal, 2016).

$$
\text { Trading Volume }=\frac{\text { jumlah saham I yang diperdagangkan pada periode } T}{\text { jumlah saham I yang beredar pada periode } \mathrm{T}}
$$


Dalam penelitian yang dilakukan, (retained earning /total asset) X3 financial distress dihitung (earning before interest and tax/total menggunakan Altman Z-score. yang asset), $\mathrm{X}_{4}$ (MVE/book value of total terdiri dari lima komponen yaitu $\mathrm{X}_{1}$ debt), $\mathrm{X}_{5}($ sales/total asset).

(working capital/total asset), $\mathrm{X}_{2}$

$$
Z=1,2 X_{1}+1,4 X_{2}+3,3 X_{3}+0,6 X_{4}+0,999 X_{5}
$$

Keterangan:

$\mathrm{Z}:$ Z-Score (bankruptcy index)

$\mathrm{X}_{1}$ : working capital dibagi total asset (modal kerja dibagi total aset)

$\mathrm{X}_{2}$ : retained earning dibagi total asset (laba ditahan dibagi total aset)

$\mathrm{X}_{3}$ : earning before interest and tax dibagi total asset (laba sebelum bunga dan pajak dibagi total aset)

$\mathrm{X}_{4}$ : market value of equity dibagi book value of total debt (harga pasar saham dibursa dibagi nilai total utang)

$\mathrm{X}_{5}$ : sales dibagi total asset (penjualan dibagi total aset)

Nilai Z adalah indeks keseluruhan fungsi multiple discriminant analysis. Menurut The Journal of Finance Altman tahun 1968 (dalam Debby, 2014, h.3), terdapat angka-angka cut off nilai z yang dapat menjelaskan apakah perusahaan akan mengalami kegagalan atau tidak pada masa mendatang dan ia membaginya ke dalam tiga kategori, yaitu:

1. Jika nilai $\mathrm{Z}<1,8$ maka termasuk perusahaan yang bangkrut.

2. Jika nilai $1,8<\mathrm{Z}<2,99$ maka termasuk grey area (tidak dapat ditentukan apakah perusahaan sehat ataupun mengalami kebangkrutan).

3. Jika nilai $\mathrm{Z}>2,99$ maka termasuk perusahaan yang tidak bangkrut.

Dalam penelitian ini menggunakan uji statistik deskriptif, uji asumsi klasik menggunakan program SPSS 23. Terdapat beberapa teknik pengujian yaitu uji normalitas, uji 
multikolinieritas, uji heterokedastisitas, dan uji autokorelasi. Kemudian juga dilakukan uji regresi berganda yaitu dengan uji F dan uji t.

\section{PEMBAHASAN}

Hasil Uji Statistik

Uji statistik deskriptif dilakukan dalam rangka memberikan gambaran secara ringkas mengenai variabel-variabel yang telah digunakan dalam penelitian dan melihat kesiapan data dalam uji selanjutnya (Ghozali,2016). Uji statistik deskriptif adakah uji untuk menjelaskan gambaran atas suatu data yang dapat dilihat dari nilai rata-rata (mean), standar deviasi, maximum, minimum. Hasil output dari uji statistik deskriptif atas variabel-variabel yang digunakan adalah stock return (Y), interest rate $\left(\mathrm{X}_{1}\right)$, investor sentiment $\left(\mathrm{X}_{2}\right)$ dan financial distress $\left(\mathrm{X}_{3}\right)$ dari 49 perusahaan manufaktur selama periode 2014-2017 yang dijadikan sampel dalam penelitian.

Tabel 1 Hasil Descriptive Statistics

\begin{tabular}{lrrrrr} 
& N & Minimum & \multicolumn{1}{c}{$\begin{array}{c}\text { Maximu } \\
\text { m }\end{array}$} & \multicolumn{1}{c}{ Mean } & \multicolumn{1}{c}{$\begin{array}{c}\text { Std. } \\
\text { Deviation }\end{array}$} \\
Stock Return & 196 & -1.2413 & 2.0625 & .101694 & .4114917 \\
Interest Rate & 196 & .0456 & .0754 & .063000 & .0128508 \\
Financial Distress & 196 & .3443 & 36.9961 & 5.267938 & 5.3764107 \\
Investor Sentiment & 196 & -2.7427 & 2.9223 & .181852 & .7413081 \\
Valid N (listwise) & 196 & & & & \\
\hline
\end{tabular}

Hasil output tampilan SPSS menunjukkan bahwa jumlah responden (N) sebesar 196. Dimana return saham dengan 49 responden memiliki nilai minimum sebesar $-1,2413$ yang diperoleh dari perusahaan PT Champion Pacific Indonesia Tbk. pada tahun 2015, dan nilai maximum sebesar 2,0625 yang diperoleh dari perusahaan PT Lionmesh Prima Tbk. pada tahun 2014.
Sedangkan nilai rata-rata (mean) dari 49 responden adalah sebesar 0,101694. Nilai standar deviasi untuk return adalah sebesar 0,4114917. Hasil uji statistik deskriptif pada variabel interest rate dengan 49 responden memiliki nilai minimum sebesar 0,0456, dan nilai maximum sebesar 0,0754 Sedangkan nilai rata-rata (mean) yang diperoleh dari 49 responden adalah 
sebesar 0,03000. Nilai standar deviasi untuk interest rate adalah sebesar 0,0128508. Hasil uji statistik deskriptif pada variabel investor sentiment dengan 49 responden memiliki nilai minimum sebesar -2,7427 yang diperoleh dari perusahaan PT Duta Pertiwi Nusantara Tbk. pada tahun 2014, dan nilai maximum sebesar 2,9223 diperoleh dari perusahaan PT H.M. Sampoerna Tbk. pada tahun 2016. Sedangkan nilai ratarata (mean) yang diperoleh dari 49 responden adalah sebesar 0,181852 . Nilai standar deviasi untuk investor sentiment adalah sebesar 0,7413081. Hasil uji statistik deskriptif pada variabel financial distress dengan 49 responden memiliki nilai minimum sebesar 0,3443 yang diperoleh dari perusahaan PT Star Petrochem Tbk. pada tahun 2014 dan nilai maximum sebesar 36,9961 yang diperoleh dari perusahaan PT H.M. Sampoerna Tbk. pada tahun 2016. Sedangkan nilai ratarata (mean) yang diperoleh dari 49 responden adalah sebesar 5,267938. Nilai standar deviasi untuk financial distress adalah sebesar 5,3764107. Uji normalitas adalah langkah pertama yang harus dilakukan dalam melakukan uji asumsi klasik. Uji normalitas digunakan untuk mengetahui apakah setiap variabel mempunyai distribusi normal atau tidak (Sugiyono,2014). Model regresi yang baik memiliki distribusi data normal atau mendekati normal

Tabel 2 Hasil One-Sample Kolmogorov-Smirnov Test

\begin{tabular}{|c|c|c|}
\hline & & $\begin{array}{l}\text { Unstandardized } \\
\text { Residual }\end{array}$ \\
\hline $\mathrm{N}$ & & 196 \\
\hline Normal Parameters ${ }^{\mathrm{a}, \mathrm{b}}$ & Mean & .0000000 \\
\hline & $\begin{array}{l}\text { Std. } \\
\text { Deviation }\end{array}$ & .25180004 \\
\hline Extreme & Absolute & .054 \\
\hline Differences & $\begin{array}{l}\text { Positive } \\
\text { Negative }\end{array}$ & $\begin{array}{r}.054 \\
-.035\end{array}$ \\
\hline $\begin{array}{l}\text { Test Statistic } \\
\text { Asymp. Sig. (2-tailed) }\end{array}$ & & $\begin{array}{r}.054 \\
.200^{\mathrm{c}, \mathrm{d}}\end{array}$ \\
\hline
\end{tabular}

Hasil dari output SPSS 23 atas uji normalitas yang dilakukan dengan uji
Kolmogrov-Smirnov yaitu ditemukan bahwa data telah terdistribusi secara 
normal karena asymptotic significance yang dihasilkan sebesar 0,200 atau 20\% yang artinya berada di atas 0,05 atau $5 \%$. Sehingga dapat disimpulkan bahwa tingkat signifikan yang dihasilkan dari uji normalitas sudah layak untuk digunakan. Uji multikolinieritas dilakukan untuk mengetahui apakah suatu model regresi memiliki korelasi antar variabel bebas. Jika antara variabel independen memiliki korelasi, maka variabel tersebut disebut tidak orthogonal (nilai korelasi antar sesama variabel independen sama dengan nol). Suatu model regresi yang baik adalah tidak terjadinya korelasi antara variabel bebas.

\section{Coefficients $^{\mathrm{a}}$}

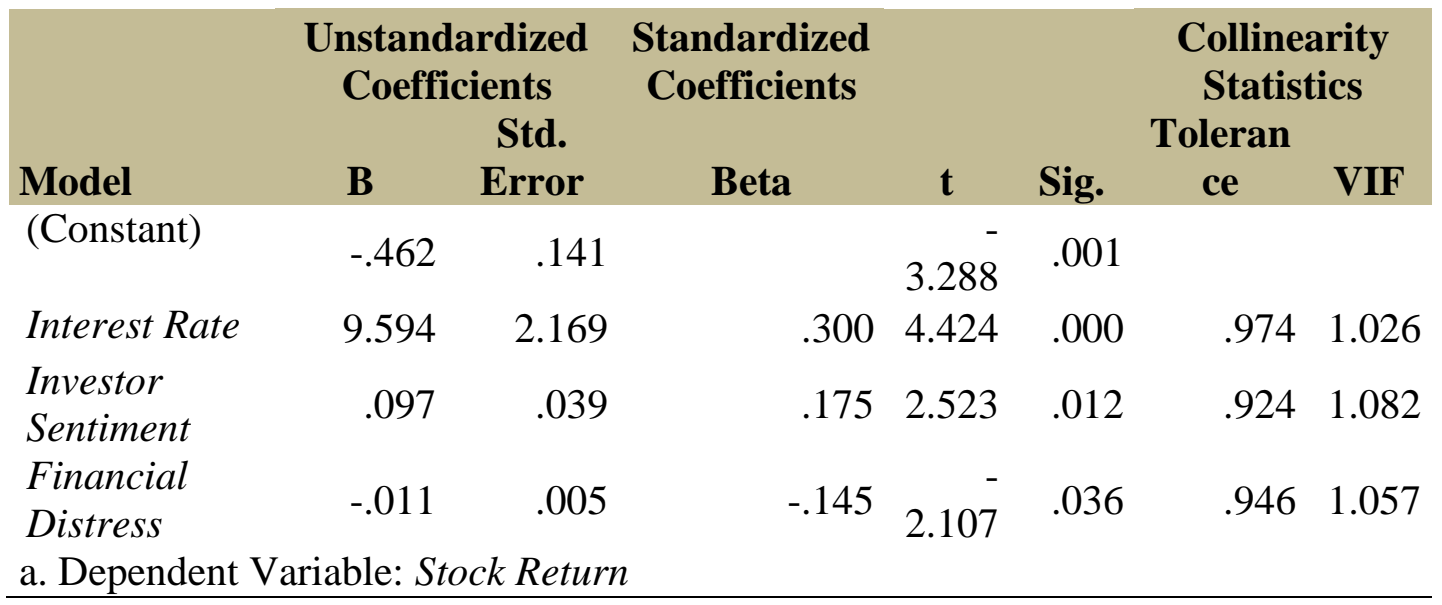

Hasil dari output SPSS 23 atas uji multikolinieritas menunjukkan bahwa nilai tolerance untuk variabel interest rate yang menggunakan sebesar 0,974, variabel investor sentiment sebesar 0,924, dan variabel financial distress yang sebesar 0,946. Berdasarkan nilai tolerance pada seluruh variabel independen tersebut, maka dapat disimpulkan bahwa data tersebut bebas dari multikolinearitas dan layak digunakan dalam penelitian ini. Hasil dari output SPSS 23 juga menunjukkan bahwa nilai variance inflation factors (VIF) pada variabel interest rate sebesar 1,026, variabel investor sentiment sebesar 1,082 dan variabel financial distress sebesar 1,057. Dari hasil 
tersebut disimpulkan bahwa data variabel independen tersebut memenuhi syarat yaitu nilai variance inflation factors (VIF) kurang dari 10. Maka dapat disimpulkan bahwa bebas dari multikolinearitas, artinya tidak terjadi korelasi antar variabel bebas sehingga layak digunakan dalam penelitian ini. Uji Heterokedastisitas dilakukan untuk menguji apakah dalam suatu model regresi terjadi ketidaksamaan antar varian dari nilai residual satu pengamatan ke pengamatan yang lain. Model regresi linear yang baik dan layak digunakan adalah yang tidak terjadi heterokedastisitas. Untuk melakukan uji heterokedastisitas, dilakukan uji Glejser.

Tabel 3 Hasil Uji Glejser

\begin{tabular}{|c|c|c|c|c|c|}
\hline \multirow[b]{2}{*}{ Model } & \multicolumn{2}{|c|}{$\begin{array}{c}\text { Unstandardized } \\
\text { Coefficients }\end{array}$} & $\begin{array}{l}\text { Standardized } \\
\text { Coefficients }\end{array}$ & \multirow[b]{2}{*}{$\mathbf{t}$} & \multirow[b]{2}{*}{ Sig. } \\
\hline & B & $\begin{array}{l}\text { Std. } \\
\text { Error }\end{array}$ & Beta & & \\
\hline (Constant) & .490 & .278 & & 1.760 & .080 \\
\hline Interest Rate & 7.801 & 4.295 & .131 & 1.816 & .071 \\
\hline $\begin{array}{l}\text { Investor } \\
\text { Sentiment }\end{array}$ & .097 & .076 & .095 & 1.282 & .201 \\
\hline $\begin{array}{l}\text { Financial } \\
\text { Distress }\end{array}$ & -.012 & .010 & -.087 & -1.182 & .239 \\
\hline
\end{tabular}

Hasil dari output SPSS 23 atas uji heterokedastisitas menunjukkan bahwa model regresi tidak mengandung heteroskedastisitas karena nilai signifikan setiap variabel berada diatas 5\%. Variabel interest rate memiliki nilai signifikan 0,071 dimana lebih dari 0,05 sehingga disimpulkan variabel interest rate tidak terjadi heterokedastisitas. Variabel investor sentiment memiliki nilai signifikan 0,201 dimana lebih dari 0,05 sehingga disimpulkan variabel investor sentiment tidak terjadi heterokedastisitas. Variabel financial distress memiliki nilai signifikan sebesar 0,239 dimana lebih besar dari 0,05 sehingga disimpulkan bahwa variabel independen financial 
distress tidak terjadi heterokedastisitas. Uji autokorelasi dilakukan untuk menguji apakah suatu model regresi linear ada korelasi antara kesalahan pengganggu pada periode $\mathrm{t}$ dengan kesalahan pengganggu pada periode $\mathrm{t}-1$ (sebelumnya). Autokorelasi muncul karena observasi yang berurutan sepanjang waktu berkaitan satu sama lainnya. Model regresi yang baik adalah regresi yang bebas dari autokorelasi.

Tabel 4 Hasil Uji Autokorelasi (Durbin-Watson)

\begin{tabular}{|c|c|c|c|c|c|}
\hline Model & $\mathbf{R}$ & $\begin{array}{c}\mathbf{R} \\
\text { Square }\end{array}$ & $\begin{array}{l}\text { Adjusted R } \\
\text { Square }\end{array}$ & $\begin{array}{c}\text { Std. Error } \\
\text { of the } \\
\text { Estimate }\end{array}$ & $\begin{array}{l}\text { Durbin- } \\
\text { Watson }\end{array}$ \\
\hline & $.377^{\mathrm{a}}$ & .142 & .129 & .3840879 & 1.979 \\
\hline
\end{tabular}

Hasil dari output SPSS 23 atas uji autokorelasi dengan menggunakan uji Durbin Watson diperoleh nilai DurbinWatson adalah 1,979 dengan jumlah data sampel (N) sebanyak 196 dan jumlah variabel independen sebanyak 3 variabel (K-3) maka nilai $d u=1,7973$, oleh karena itu nilai $d w$ sebesar 1,979 berada diantara $d u$ yaitu 1.7397 , dan 4$d u$ yaitu 2.2027. Maka berdasarkan hasil tersebut, dapat disimpulkan bahwa model regresi tidak terjadi autokorelasi. Setelah melakukan uji statistik deskriptif, selanjutnya dilakukan uji hipotesis menggunakan uji analisis regresi berganda dalam penelitian ini. Analisis regresi berganda dilakukan untuk mengukur kekuatan dan arah hubungan antara return saham (variabel dependen) dengan, interest rate, investor sentiment, dan financial distress (variabel independen) pada perusahaan manufaktur di Bursa Efek Indonesia periode 2014-2017 dengan tingkat signifikansi 5\%. Model regresi dalam penelitian ini adalah sebagai berikut :

$$
\mathrm{Y}=\alpha+\beta 1 X 1+\beta 2 X 2+\beta 3 X 3+\beta 4 X 4+\varepsilon
$$


Keterangan :

$\mathrm{Y}=$ Stock Return

$\mathrm{X} 1=$ Interest Rate

$\mathrm{X} 2$ = Investor Sentiment

X3 = Financial Distress

$\propto=$ Konstanta

$\beta 1-\beta 3=$ Koefisien regresi variabel independen

$\varepsilon=$ Tingkat kesalahan (error)

Tabel 5 Uji Analisis Regresi

\begin{tabular}{lrrrrr} 
& \multicolumn{2}{c}{$\begin{array}{l}\text { Unstandardized } \\
\text { Coefficients }\end{array}$} & $\begin{array}{c}\text { Standardized } \\
\text { Coefficients }\end{array}$ & & \\
Model & \multicolumn{1}{c}{ B } & Std. Error & \multicolumn{1}{c}{ Beta } & \multicolumn{1}{c}{ t } & \multicolumn{1}{c}{ Sig. } \\
(Constant) & -.462 & .141 & & -3.288 & .001 \\
$\begin{array}{l}\text { Interest Rate } \\
\text { Investor }\end{array}$ & 9.594 & 2.169 & .300 & 4.424 & .000 \\
$\begin{array}{l}\text { Sentiment } \\
\text { Financial }\end{array}$ & .097 & .039 & .175 & 2.523 & .012 \\
Distress & -.011 & .005 & -.145 & -2.107 & .036 \\
\hline
\end{tabular}

$\mathrm{Y}=-0,462+9,594 \mathrm{IR}+0,097 \mathrm{IS}+-0,011 \mathrm{FD}+\varepsilon$

Keterangan :

$\mathrm{Y}=$ Stock Return

IS = Investor Sentiment

$\mathrm{IR}=$ Interest Rate

$\mathrm{FD}=$ Financial Distress

$\propto=$ Konstanta

$\varepsilon=$ error

Dari persamaan regresi yang sudah ditampilkan, koefisien konstanta $\propto$ sebesar -0,462 yang menunjukkan bahwa apabila variabel independen tersebut sama dengan 0 , maka variabel dependen bernilai sebesar -0.462 . Nilai koefisien $\beta 1$ untuk interest rate adalah sebesar 9,594 yang berarti nilai tersebut 
mempunyai arah perubahan yang searah antara variabel interest rate dengan variabel stock return. Yang artinya jika interest rate mengalami kenaikan atau penurunan sebesar satu satuan, maka stock return juga akan mengalami kenaikan atau penurunan sebesar 9,594 dengan asumsi variabel $\beta_{2}$ dan $\beta_{3}$ sama dengan nol. Nilai koefisien $\beta_{2}$ untuk investor sentiment adalah sebesar 0,097. yang berarti nilai tersebut mempunyai arah perubahan yang searah antara variabel investor sentiment dengan variabel stock return. Yang artinya jika investor sentiment mengalami kenaikan atau penurunan sebesar satu satuan, maka stock return juga akan mengalami kenaikan atau penurunan sebesar 0,097 dengan asumsi variabel $\beta 1$ dan $\beta 3$ sama dengan nol. Nilai koefisien $\beta 3$ untuk financial distress adalah sebesar $-0,011$ yang berarti nilai tersebut mempunyai arah perubahan yang terbalik antara variabel investor sentiment dengan variabel stock return. Yang artinya jika financial distress mengalami kenaikan sebesar satu satuan, maka stock return akan mengalami penurunan sebesar 0,011, sebaliknya jika financial distress mengalami penurunan sebesar satu satuan, maka stock return akan mengalami kenaikan sebesar 0,011dengan asumsi variabel $\beta 1$ dan $\beta 2$ sama dengan nol. Uji adjusted $\mathrm{R}^{2}$ dilakukan untuk menguji seberapa besar pengaruh variabel independen terhadap variabel dependen.

Tabel 6 Hasil Uji Koefisien Determinasi

\begin{tabular}{|c|c|c|c|c|c|}
\hline Model & $\mathbf{R}$ & $\begin{array}{c}\text { R } \\
\text { Square }\end{array}$ & $\begin{array}{c}\text { Adjusted R } \\
\text { Square }\end{array}$ & $\begin{array}{c}\text { Std. Error } \\
\text { of the } \\
\text { Estimate }\end{array}$ & $\begin{array}{l}\text { Durbin- } \\
\text { Watson }\end{array}$ \\
\hline & $.377^{\mathrm{a}}$ & .142 & .129 & .3840879 & 1.979 \\
\hline
\end{tabular}

Hasil dari output SPSS 23 menunjukkan bahwa nilai adjusted R-Square sebesar 0,129 yang berarti sebesar $12,9 \%$. Dapat disimpulkan bahwa interest rate, investor sentiment, dan financial distress dapat menjelaskan return saham sebesar $12,9 \%$ dan sisa sebesar $87,1 \%$ dijelaskan oleh variabel lain yang tidak dimasukkan didalam penelitian ini. Nilai R digunakan untuk menunjukkan hubungan antara interest rate, investor sentiment, dan financial distress terhadap return saham. Nilai koefisien korelasi terletak diantara 0 sampai 1 
atau 0 sampai -1. Apabila nilai koefisien korelasi semakin mendekati 1 atau -1, maka hubungan antara variabel independen dan variabel dependen semakin erat dan sebaliknya. Nilai R sebesar 0.142, dapat disimpulkan bahwa hubungan korelasi antara interest rate, investor sentiment, dan financial distress terhadap return adalah lemah dan positif. Uji-F pada dasarnya menunjukkan apakah semua variabel independen atau bebas yang dimasukan dalam model mempunyai pengaruh secara bersama-sama terhadap variabel dependen (Ghozali, 2013:142). Tingkat signifikan yang digunakan adalah 5\% ( $\alpha$ $=5 \%)$. Apabila nilai signifikan < dari 0.05 , maka model dinyatakan dapat memprediksi nilai pada variabel dependen. Berikut adalah langkah untuk melakukan uji-F, pertama lakukan perumusan hipotesis, kemudian lakukan penentuan nilai tingkat signifikan $(\alpha)$, dalam penelitan ini nilai signifikan yang digunakan sebesar 5\%, langkah selanjutnya bandigkan nilai signifikan dari hasil uji olah data dengan, kemudian menetukan kesimpulan, jika nilai $\mathrm{Sig}>\alpha$, maka $\mathrm{H}_{0}$ tidak ditolak, nilai $\operatorname{Sig} \leq \alpha$, maka $\mathrm{H}_{0}$ ditolak.

Tabel 7 Hasil Uji Anova

\begin{tabular}{crrrrr} 
& \multicolumn{2}{c}{ ANOVA $^{\mathbf{a}}$} & & & \\
Model & \multicolumn{1}{c}{$\begin{array}{c}\text { Sum of } \\
\text { Squares }\end{array}$} & \multicolumn{1}{c}{ df } & \multicolumn{1}{c}{$\begin{array}{c}\text { Mean } \\
\text { Square }\end{array}$} & \multicolumn{1}{c}{ F } & \multicolumn{1}{c}{ Sig. } \\
Regression & 4.694 & 3 & 1.565 & 10.606 & $.000^{b}$ \\
Residual & 28.325 & 192 & .148 & & \\
Total & 33.018 & 195 & & &
\end{tabular}

a. Dependent Variable: Stock Return

b. Predictors: (Constant), Financial Distress, Interest Rate, Investor Sentiment

Hasil output SPSS 23 maka dapat disimpulkan bahwa nilai $\mathrm{F}$ sebesar 10,606 dengan nilai signifikan sebesar 0,000. Nilai signifikan yang dihasilkan dari uji F tersebut lebih kecil daripada $\propto$
$=0,05$ sehingga dapat disimpulkan bahwa variabel independen secara bersama-sama memiliki pengaruh terhadap variabel dependen dengan tingkat keyakinan 95\%. Uji $\mathrm{t}$ pada dasarnya dilakukan untuk menunjukan 
seberapa jauh pengaruh satu variabel independen secara individual dalam menerangkan variasi variabel dependen (Ghozali, 2013:136). Tingkat signifikan yang digunakan sebesar 5\% $(\alpha=0.05)$. Apabila nilai signifikan < dari 0.05, maka model dinyatakan memiliki pengaruh dan mampu menjelaskan variabel dependen. Berikut adalah langkah- langkah melakukan uji $\mathrm{t}$ :
Pertama lakukan perumusan hipotesis, kemudian lakukan penentuan nilai tingkat signifikan $(\alpha)$, dalam penelitan ini nilai signifikan yang digunakan sebesar 5\%, langkah selanjutnya bandigkan nilai signifikan dari hasil uji olah data dengan, kemudian menetukan kesimpulan, jika nilai Sig $>\alpha$, maka $\mathrm{H}_{0}$ tidak ditolak, nilai $\mathrm{Sig} \leq \alpha$, maka $\mathrm{H}_{0}$ ditolak.

Tabel 8 Hasil Uji t

\begin{tabular}{|c|c|c|c|c|c|c|c|}
\hline \multirow[b]{2}{*}{ Model } & \multicolumn{2}{|c|}{$\begin{array}{r}\text { Unstandard } \\
\text { Coefficients } \\
\text { Std. }\end{array}$} & \multicolumn{2}{|l|}{$\begin{array}{c}\text { Standard } \\
\text { Coefficients }\end{array}$} & & \multicolumn{2}{|c|}{$\begin{array}{l}\text { Collinearity } \\
\text { Statistics } \\
\text { Toleran }\end{array}$} \\
\hline & B & Error & Beta & $\mathbf{t}$ & Sig. & ce & VIF \\
\hline 1 (Constant) & -.462 & .141 & & 3.288 & .001 & & \\
\hline $\begin{array}{l}\text { Interest } \\
\text { Rate }\end{array}$ & 9.594 & 2.169 & .300 & 4.424 & .000 & .974 & $\begin{array}{r}1.02 \\
6\end{array}$ \\
\hline $\begin{array}{l}\text { Investor } \\
\text { Sentiment }\end{array}$ & .097 & .039 & .175 & 2.523 & .012 & .924 & $\begin{array}{r}1.08 \\
2\end{array}$ \\
\hline $\begin{array}{l}\text { Financial } \\
\text { Distress }\end{array}$ & -.011 & .005 & -.145 & 2.107 & .036 & .946 & $\begin{array}{r}1.05 \\
7\end{array}$ \\
\hline a. Dependent & able: & $\mathrm{k}$ Ret & & & & & \\
\hline
\end{tabular}

Hasil output SPSS 23, hasil uji t pada variabel interest rate menunjukkan bahwa tingkat signifikan adalah 0,000 dimana dibawah dari 0,05 dan koefisien regresi memiliki nilai positif 9,594 sehingga dapat disimpulkan variabel interest rate berpengaruh positif dan signifikan terhadap variabel stock return. Kesimpulannya $\mathrm{H}_{1}$ ditolak, $\mathrm{Ha}_{1}$ diterima. Dari hasil output SPSS 23, hasil uji $\mathrm{t}$ pada variabel investor sentiment menunjukkan bahwa tingkat signifikan adalah 0,012 di mana kurang dari 0,05 dan koefisien regresi memiliki nilai positif 0,097 sehingga dapat disimpulkan variabel investor sentiment berpengaruh positif dan signifikan terhadap variabel stock return. Kesimpulannya $\mathrm{H}_{02}$ ditolak, $\mathrm{Ha}_{2}$ diterima. Dari hasil output SPSS 23, 
hasil uji $\mathrm{t}$ pada variabel financial distress menunjukkan bahwa tingkat signifikan adalah 0,036 di mana kurang dari 0,05 dan koefisien regresi memiliki nilai negatif $-0,011$ sehingga dapat

\section{KESIMPULAN}

Dari hasil pengujian hipotesis terhadap variabel interest rate dapat disimpulkan variabel interest rate berpengaruh positif dan signifikan terhadap stock return. Hasil penelitian ini memiliki kesamaan dengan hasil penelitian Akbar Faoriko (2013), Puspitadewi dan Henny (2016) yang menyimpulkan bahwa variabel interest rate memiliki pengaruh yang signifikan dan positif terhadap variabel stock return. Dari hasil pengujian hipotesis terhadap variabel investor sentiment dapat disimpulkan variabel investor sentiment berpengaruh positif dan signifikan terhadap stock return. Hasil penelitian ini memiliki kesamaan dengan penelitian dari Anusakumar, Ali, dan Choo Wei (2017) yang menyatakan bahwa variabel investor sentiment memiliki pengaruh yang signifikan dan positif terhadap stock return. Dari hasil pengujian hipotesis terhadap variabel financial distress dapat disimpulkan variabel financial distress berpengaruh negatif disimpulkan variabel financial distress berpengaruh negatif dan signifikan terhadap variabel stock return. Kesimpulannya $\mathrm{H}_{03}$ ditolak, $\mathrm{Ha}_{3}$ diterima.

dan signifikan terhadap stock return. Hasil penelitian ini memiliki kesamaan dengan penelitian Lailatul Jannah (2015) yang menyatakan bahwa variabel financial distress memiliki pengaruh yang signifikan dan negatif terhadap variabel stock return. Hasil olah data menunjukkan bahwa variabel independen dalam penelitian ini telah memenuhi syarat uji asumsi klasik, maka dapat disimpulkan bahwa variabel independen yang digunakan sudah layak untuk di uji. Dari uji statistik $t$ diperoleh hasil bahwa variabel interest rate berpengaruh positif terhadap stock return dengan nilai signifikansi sebesar 0,000 dimana hasil tersebut lebih kecil dari 0,05 maka dapat disimpulkan Ha1 diterima. Dari uji statistik t diperoleh hasil bahwa investor sentiment berpengaruh positif terhadap stock return dengan nilai signifikansi sebesar 0,012 dimana hasil tersebut lebih kecil dari 0,05 maka dapat disimpulkan $\mathrm{Ha}_{2}$ diterima. Dari uji statistik t diperoleh hasil bahwa financial distress 
berpengaruh negatif terhadap stock return dengan nilai signifikansi sebesar 0,036 di mana hasil tersebut lebih kecil dari 0,05 maka dapat disimpulkan $\mathrm{Ha}_{3}$ diterima. Penelitian ini mempunyai beberapa keterbatasan, yaitu sebagai berikut: (1) Subjek penelitian dibatasi hanya pada perusahaan manufaktur selama periode 2014-2017 yang terdaftar di Bursa Efek Indonesia (BEI),

\section{DAFTAR PUSTAKA}

Aissia, D. B. (2016). Home and foreign investor sentiment and the stock returns. The Quarterly Review of Economics and Finance, 59, 7177.

Al Oshaibat, S. (2016). The

Relationship Between Stock Returns And Each Of Inflation, Interest Rates, Share Liquidity And Remittances Of Workers In The Amman Stock Exchange. Journal Of Internet Banking And Commerce, August 2016, Vol. 21, No. 2

Anusakumar, S. V., Ali, R., \& Hooy, C. W. (2017). The effect of investor sentiment on stock returns: Insight from emerging Asian markets. Asian Academy of Management Journal of Accounting and Finance, 13(1), 159-178.

Bachtriyoh, Rapige. (2013). The

Effect's of Leverage, Return Financial, and Stock Return On Asean Stcock Exchange. Word Journal Economic's Accounting, 5 (8), pp: 178-234.
(2) Variabel - variabel independen yang berpengaruh terhadap stock return dibatasi hanya pada interest rate, investor sentiment, dan financial distress, (3) Besarnya pengaruh variabel interest rate, investor sentiment, dan financial distress terhadap stock return yang ditunjukkan melalui nilai $\mathrm{R}^{2}$ sebesar 0,129.

Boediono. (2014). Seri Sinopsis

Pengantar Ilmu - No. 5 Ekonomi Makro. Yogyakarta: BPFE

Brigham, E. F. \& J. F. Houston. (2014). Dasar-Dasar Manajemen Keuangan. Jakarta: Salemba Empat

Drescher, F., (2014). Insolvency Timing and Managerial DecisionMaking. Springer, Munchen.

Ellen \& Juniarti. (2013). Penerapan Corporate Governance, Dampaknya Terhadap Prediksi Financial Distress pada Sektor Aneka Industri dan Barang Konsumsi. Business Accounting Review, Vol.1, No.2

Faoriko Akbar, Riko (2013) Pengaruh Inflasi, Suku Bunga Dan Nilai Tukar Rupiah, Terhadap Return Saham Di Bursa Efek Indonesia. S1 thesis, Fakultas Ekonomi. 
Fadhlillah, Faisal. (2017). Pengaruh

Non-Linear Sentimen Investor

Terhadap Return Pada

Perusahaan Manufaktur Di

Bursa Efek Indonesia Tahun

2014-2015. Jurnal Ilmiah

Mahasiswa Ekonomi

Manajemen Vol. 2, No. 3, Agustus 2017: 246-259

Ghozali, Imam. (2013). Aplikasi

Analisis Multivariate dengan

Program SPSS. Edisi Ketujuh.

Semarang: Badan Penerbit

Universitas Diponegoro.

Ghozali, Imam. (2016). Aplikasi

Analisis Multivariete Dengan

Program IBM SPSS 23.

Semarang: Badan Penerbit

Universitas Diponegoro

Gitman,J Lawrence, Joehnk, Michael and Billingsley, S Randall. (2014). Personal Financial Planning. USA: Cengage Learning

Gitman,J Lawrence, Joehnk, Michael and Billingsley, $S$ Randall. (2014). Personal Financial Planning. USA: Cengage Learning

Hadi, Nor. (2013). Pasar Modal: Acuan Teoritis dan Praktis Investasi di Instrumen Keuangan Pasar Modal. Yogyakarta : Graha Ilmu

Hayat, Yasmeen dan Syed Nisar Ahmed. (2014). Impact of Inflation on Stock Ex change Market Returns, European Aca demic Research, Vol. I, Issue 11/ February 2014

Iskandarsyah, dkk. (2014). Pengaruh
Likuiditas, Financial Leverage, dan Profitabilitas terhadap Dividen Tunai pada Perusahaan Yang Terdaftar Dalam Jakarta Islamic Index. Jurnal Magister Akuntansi ISSN 2302-0164 pp. 36-43 Volume 3 No. 4.

Jannah, Lailatul. (2015). Pengaruh

Financial Distress dan Ukuran Perusahaan terhadap Return Saham pada Perusahaan Sektor Pertambangan yang Terdaftar di BEI Tahun 2014. Skripsi, Jurusan Manajemen, Fakultas Ekonomi, Universitas Negeri Malang

Jensen, M. C and Meckling, W.H. (1976). Theory of the Firm : Managerial Behavior, Agency Costs and Ownership Structure . Journal of Financial Economics, Oktober, 1976, V. 3, No. 4, pp.305-360

Jogiyanto, Hartono (2014). Teori

Portofolio dan Analisis Investasi. Yogyakarta: BPFE.

Julini, Debby, Yansen Siahaan, Mahaitin Sinaga, \& Rosanna Purba. (2014). Pengaruh Financial Distress (Altman Z-Score) terhadap Return Saham pada Perusahaan Sektor Aneka Industri yang Terdaftar di Bursa Efek Indonesia. Jurnal SULTANIST, Vol.2, No.2.

Fisher, K. L., \& Statman, M. (2000). Investor Sentiment and Stock Returns. Financial Analysts Journal, 56, 16-23. 
Maulina Agustya, Faisal (2017).

Sentimen Investor Dan

Ekspektasi Pertumbuhan Laba Jangka Panjang Pada Industri Non Keuangan Di Indonesia. Vol.3

Michael, Jamie. (2014). The Effcets

Leverage On Stock Opname In World Of Bank. International Journal, 9 (8), pp: 479-517.

Mirantiani, Desi Sutria. (2016).

Pengaruh Laba Akuntansi, Harga Saham, Leverage, dan Laba Tunai terhadap Dividen Kas pada Perusahaan Property dan Real Estate yang terdaftar di BEI pada tahun 2012-2014. Skripsi Universitas Muhammadiyah Purwokerto.Nugroho.

Mokhamad, (2012), Analisis Prediksi

Financial Distress dengan Menggunakan Model Altman ZScore Modifikasi 1995 Pada Perusahaan Manufaktur yang Go Public Di Indonesia, Skripsi, Semarang : Universitas Diponegoro.

Opera, Dragos Stefan dan Brad, Laura. (2014). Investor Sentiment and Stock Returns: Evidence from Romania. International Journal of Academic Research in Accounting, Finance and Management Sciences, Vol. 4, No.2, pp. 19-25

Ouma, Wycliffe Nduga, Dr. Peter Muriu. (2014). The impact of macroeconomic variables on stock market returns in Kenya, International Journal of
Business and Commerce Vol. 3 , No.11: July

Puspitadewi, Cokorda Istri Indah, \&

Henny Rahyuda. (2016). Pengaruh DER, ROA, PER, dan EVA terhadap Return Saham

Pada Perusahaan Food and Beverage di BEI.

Sobri, Amin. (2018). Pengaruh

Financial Distress Terhadap

Return Saham Dengan

Manajemen Laba Sebagai

Variabel Moderasi (Studi

Empiris Pada Perusahaan

Pertambangan Yang Terdaftar

Di Bursa Efek Indonesia Tahun

2013-2017), Skripsi, Bandar

Lampung : Universitas

Lampung.

Sugiyono. (2014). Metode penelitian

Kuantitatif Kualitatif dan $R \& D$.

Bandung: Alfabeta

Sunariyah. (2013). Pengantar

Pengetahuan Pasar Modal.

Yogyakarta: UPP-STIM YKPN.

Vinh, V. (2015). Using Accounting

Ratios In Predicting Financial

Distress. Journal of Economics and Develpoment, 27 (2), 41-49. ISSN: 1859-0020.

Yaredeta, Norma. (2014) Pengaruh Dividend per Share, Return on Equity, Net Profit Margin, Likuiditas Saham, Pertumbuhan Penjualan Terhadap Harga Saham pada Perusahaan Pertambangan Listing di Bursa Efek Indonesia. Skripsi, Bandung: Universitas Widyatama. 
Yunanto, Linang. (2017). Pengaruh laba, pertumbuhan perusahaan, dan arus kas terhadap kondisi financial distress (studi kasus pada perusahaan pertambangan sub sektor batubara, logam, dan mineral lainnya yang terdaftar di BEI). Jurnal mahasiswa, Fakultas Ekonomi Universitas PGRI Yogyakarta

Zahara, Devi, (2013), Analisis Laporan Keuangan Untuk Memprediksi Financial Distress (Kesulitan Keuangan) Pada Kopdit/Cu. Saroha Pematangsiantar, Skripsi Pematangsiantar : STIE Sultan Agung 